\title{
Asupan zink dan magnesium makanan dengan disfungsi ereksi pada penderita sindrom metabolik
}

The relationship between zinc and magnesium dietary intake in patient with erection dysfunction and metabolic syndrome

\author{
Saraheni $^{1}$, I Dewa Putu Pramantara ${ }^{2}$, Herni Astuti ${ }^{3}$
}

\begin{abstract}
Background: Metabolic syndrome (MetS) is a disease of disorder of lipid and non lipid metabolism. The West of Scotland Coronary Prevention Study found that men with MetS had probability 3.7 dysfunction of erection (ED) by using International Index of Erectile Function (IIEF). Patient with heart disease had risk 2 times to get ED, hypertension was 1.5-2 times, DM was 3-4 times, depression was 2-3.5 times, testosterone deficiency syndrome (TDS) was 1.5-2 times, and high cholesterol was 4 times. The nutrient deficiency of zinc (Zn) and magnesium (Mg) was suspected being the main component which had role in resisting a sexuality growth and maturation process. Objective: Knowing the correlation of $\mathrm{Zn}$ and $\mathrm{Mg}$ feeding with erection dysfunction in MetS person. Method: This study was observational analytic study, with case control design in patient aged 30-60 years old. The respondent in this study was people with MetS according to WHO criterion. There was 82 patient devided in to two groups, consist of 41 cases with MetS and ED, 41 cases with normal patient. The data collected by interview, laboratory assessment and antropometric measurement. The data analysis using univariate, bivariate and multivariate analysis using multiple logistic regression. Results: There was significant correlation between $\mathrm{Zn}$ feeding and $\mathrm{ED}(\mathrm{OR}=7.15 ; 95 \% \mathrm{Cl}=1.47-34.71 ; p=0.007)$ and there was significant correlation between $\mathrm{Mg}$ feeding with $\mathrm{ED}(\mathrm{OR}=3.34 ; 95 \% \mathrm{Cl}=1.07-10.4 ; \mathrm{p}=0.033)$. The end result of multivariate analysis showed the risk variable to the ED event, that were $Z n$ feeding with $O R=15.41$. If the intake of $Z n$ accompanied with risk factors associated as a cause of ED, multivariate analysis showed HbAlc's degree with $O R=12.57$; triglyceride (OR=10.47); blood pressure (OR=5.82); and abdominal obesity $(O R=6.94)$. Result shows that these risk factors can aggravate or anticipate the onset of disfunction erection beside low Zn intake. Conclusion: There were statistically significant correlation between $\mathrm{Zn}$ and $\mathrm{Mg}$ feeding with erection dysfunction in MetS patient.
\end{abstract}

KEY WORDS: metabolic syndrome, erection dysfunction, zinc and magnesium

\begin{abstract}
ABSTRAK
Latar belakang: Sindrom metabolik (MetS) adalah kelainan metabolik pada lipid maupun non-lipid. The West of Scotland Coronary Prevention Study menemukan bahwa pria dengan MetS memiliki risiko 3,7 kali lipat terkena disfungsi ereksi (DE) dan berdasarkan IIEF-5 didapatkan 50\% dari pasien MetS tersebut mengalami DE. Pasien dengan penyakit jantung 2 kali lebih berisiko terkena DE; hipertensi 1,5-2 kali; DM 3-4 kali; depresi 2-3,5 kali; testosterone deficiency syndrome (TDS) 1,5-2 kali; dan kolesterol tinggi 4 kali. Defisiensi zat gizi zink $(\mathrm{Zn})$ dan magnesium $(\mathrm{Mg})$ diduga berperan dalam penghambatan proses pertumbuhan dan pematangan seksualitas. Tujuan: Mengetahui hubungan asupan $\mathrm{Zn}$ dan Mg dengan DE pada penderita MetS. Metode: Penelitian observasional analitik dengan rancangan case control pada pasien berusia 30-60 tahun. Subjek penelitian adalah penderita MetS dengan kriteria WHO sebanyak 82 pasien (41 kasus dengan DE dan 41 kontrol yang tidak DE). Data diperoleh dengan cara wawancara, hasil laboratorium, dan pengukuran antropometri. Analisis data meliputi analisis univariat, bivariat, dan multivariat menggunakan uji regresi logistik ganda. Hasil: Ada hubungan yang bermakna antara asupan $\mathrm{Zn}$ dengan $\mathrm{DE}(\mathrm{OR}=7,15 ; 95 \% \mathrm{Cl}=1,47-34,71 ; \mathrm{p}=0,007)$, demikian juga antara asupan $\mathrm{Mg}$ dengan $\mathrm{DE}(\mathrm{OR}=3,34 ; 95 \% \mathrm{Cl}=1,07-10,49 ; \mathrm{p}=0,033)$. Variabel yang paling berisiko terhadap kejadian DE adalah asupan $\mathrm{Zn}(\mathrm{OR}=15,41)$. Apabila asupan $\mathrm{Zn}$ disertai faktor-faktor risiko yang berkaitan sebagai penyebab DE, hasil analisis multivariat menunjukkan kadar HbA1c yang tidak terkontrol dengan nilai $\mathrm{OR}=12,57$; kadar trigliserida yang tinggi $(\mathrm{OR}=10,47)$; hipertensi $(\mathrm{OR}=5,82)$; dan obesitas abdominal $(\mathrm{OR}=6,94)$. Faktor-faktor tersebut menunjukkan hasil yang harus dipertimbangkan karena dapat memperburuk atau mengantisipasi terjadinya DE di samping asupan Zn yang kurang. Simpulan: Ada hubungan yang bermakna secara statistik antara asupan $\mathrm{Zn}$ dan $\mathrm{Mg}$ dengan DE pada pasien sindrom metabolik.
\end{abstract}

KATA KUNCI: sindrom metabolik, disfungsi ereksi, zink dan magnesium

\footnotetext{
Korespondensi: Instalasi Gizi Rumah Sakit Umum Daerah (RSUD) Abdul Wahab Syahranie Samarinda, Jl. Palang Merah Indonesia, Samarinda, Kalimantan Timur, e-mail: henidioh@yahoo.com

Bagian Penyakit Dalam Rumah Sakit Umum Pusat (RSUP) Dr. Sardjito, Jl. Kesehatan No. 1, Sekip, Yogyakarta 55284

${ }^{3}$ Instalasi Gizi Rumah Sakit Umum Pusat (RSUP) Dr. Sardjito, Jl. Kesehatan No. 1, Sekip, Yogyakarta 55284
} 


\section{PENDAHULUAN}

Indonesia pada bidang kesehatan masih berjuang memerangi penyakit infeksi, kurang gizi, dan masalah kelebihan gizi (non communicable diseases). Fenomena gizi lebih ini sering disebut "new world syndrome" yang telah menimbulkan beban sosial ekonomi serta kesehatan masyarakat secara global (1). Lebih lanjut, sekumpulan kelainan metabolik, baik lipid maupun non-lipid disebut sindrom metabolik (MetS). Kelainan metabolik tersebut meliputi diabetes mellitus (DM), obesitas sentral, dislipidemia aterogenik, kadar trigliserida meningkat dan kadar kolesterol high density lipoprotein (HDL) rendah, serta hipertensi, kriteria ini menurut National Cholesterol Education Program Adult Treatment Panel III (NCEP ATP-III) (2).

Sindrom metabolik menjadi ancaman bagi kesehatan masyarakat di abad 21 (3). Prevalensi MetS yang tinggi dilaporkan pada penduduk dewasa di Amerika Serikat yaitu sekitar 60 juta penduduk, pada usia 60-69 tahun meningkat $43,5 \%$ berisiko menderita disfungsi ereksi (DE) (4). The West of Scotland Coronary Prevention Study melakukan penelitian pada 6000 orang pria selama lima tahun, menemukan bahwa pria dengan MetS berisiko 3,7 kali lipat terkena DE. Pasien dengan penyakit jantung 2 kali berisiko terkena DE; hipertensi 1,5-2 kali; DM 3-4 kali; depresi 2-3,5 kali; dan kolesterol tinggi sebanyak 4 kali berisiko terkena DE (5). Penelitian NCEP ATP-III yang dilakukan pada 268 pasien dengan faktor risiko penyakit degeneratif diperoleh hasil $74 \%$ mengalami MetS, berdasarkan International Index of Erectile Function (IIEF) diperoleh 50\% dari pasien MetS tersebut mengalami DE, terkait gangguan pada disfungsi endotelia dan aterosklerosis (6).

Disfungsi ereksi adalah ketidakmampuan mencapai atau mempertahankan fungsi ereksi yang cukup untuk aktivitas seksual yang memuaskan. Di Indonesia, diduga $10 \%$ pria menikah mengalami DE (7). Penyakit vaskuler merupakan penyebab yang paling sering menimbulkan $\mathrm{DE}$, dari semua penyakit vaskuler, aterosklerosis adalah yang terbanyak melalui mekanisme berkurangnya tekanan perfusi pada arteri dan aliran darah ke lakunar pada korpus kavernosa (8). Samarinda adalah ibu kota Provinsi Kalimantan Timur yang berpenduduk 2.704 .851 jiwa dengan prevalensi obesitas (IMT $>27 \mathrm{~kg} / \mathrm{m}^{2}$ ) sebesar 18,5\%; obesitas sentral 20,1\%; diabetes $1,3 \%$; dan hipertensi 39,7\% (9). Lebih lanjut, dijelaskan bahwa makanan yang sesuai kebutuhan tubuh dan kebugaran berkaitan erat dalam membantu menurunkan risiko serangan penyakit. Zink ( $\mathrm{Zn}$ ) memegang peranan esensial dalam semua sel, perkembangan fungsi reproduksi pria dan spermatogenesis, terutama perubahan testosteron menjadi dehidrotestosteron yang aktif (10). Defisiensi $\mathrm{Zn}$ diduga sebagai komponen zat gizi utama yang berperan dalam penghambatan proses pertumbuhan dan pematangan seksualitas (11).

Zink berperan penting dalam memelihara sistem imun (12). Sebagai katalisator, enzim superoksida dismutase (SOD) membutuhkan tembaga $(\mathrm{Cu})$ dan $\mathrm{Zn}$ yang berada di dalam sitosol semua sel terutama eritrosit. Enzim tersebut diduga memusnahkan anion superoksida yang merusak, yang dapat memicu terbentuknya plak pada proses aterosklerosis (13). Sementara itu, magnesium $(\mathrm{Mg})$ memegang peranan penting dalam 300 jenis sistem enzim di dalam tubuh. Magnesium bertindak di semua sel jaringan lunak sebagai katalisator dalam reaksi-reaksi biologik. Di dalam cairan ekstrasel, $\mathrm{Mg}$ berperan dalam transmisi saraf, kontraksi otot, dan pembekuan darah. Magnesium mencegah penggumpalan darah yang dapat menyebabkan aterosklerosis dalam arteri dan melemaskan saraf (14).

Masalah DE ini merupakan masalah serius yang menjadi salah satu penyebab utama gangguan psikologis yang berefek pada penurunan kualitas hidup seorang laki-laki dalam kehidupannya (15) dan lebih diwaspadai bahwa DE dapat mengganggu kualitas hidup penderita karena depresi (16). Pada umumnya, DE dapat terjadi pada semua pria dari berbagai kalangan umur yang mengakibatkan stres dan berdampak pada penurunan kualitas hidup sehingga mengakibatkan ketidakpuasan dalam relasi seksual dengan pasangannya yang pada akhirnya menurunkan kebahagiaan hidup penderitanya $(17,18)$. Berdasarkan latar belakang tersebut, tujuan penelitian ini adalah untuk mengetahui hubungan asupan $\mathrm{Zn}$ dan $\mathrm{Mg}$ dengan DE pada penderita MetS, mengingat zat gizi ini memegang peranan esensial dalam semua sel dan bila terjadi defesiensi zat gizi ini akan menyebabkan perubahan yang luas pada berbagai macam reaksi di dalam tubuh. 


\section{BAHAN DAN METODE}

Jenis penelitian ini adalah observasional dengan rancangan penelitian kasus kontrol. Kelompok MetS yang mengalami DE disebut kelompok kasus dan kelompok MetS yang tidak mengalami DE disebut kelompok kontrol yang dibandingkan keterpaparannya terhadap asupan zat gizi Zn dan Mg. Penelitian dilakukan di RSUD Abdul Wahab Sjahranie Samarinda, tepatnya di poliklinik rawat jalan pada bulan November 2010 sampai Januari 2011. Populasi penelitian adalah seluruh pasien MetS, berjenis kelamin laki-laki, dengan macthing umur antara 30-60 tahun. Kriteria inklusi subjek penelitian adalah menikah dan istri masih hidup (19), masih melakukan hubungan seksual dalam 3 bulan terakhir, dalam keadaan stabil dan komunikatif, menderita DM tipe 2 disertai sedikitnya dua faktor lain yang telah ditentukan sesuai dengan kriteria World Health Organization (WHO) untuk MetS. Subjek akan dieksklusi jika memenuhi kriteria yaitu penderita
DM dengan komplikasi gagal ginjal terminal atau sudah hemodialisis, menderita penyakit gagal jantung, gagal hati, penderita dengan penyakit keganasan, DM tipe 1 dan tipe lain yang telah didiagnosis oleh dokter.

Besar sampel minimal pada penelitian ini dihitung menggunakan rumus besar sampel untuk studi kasus kontrol (20) dengan tingkat kemaknaan 95\%, kekuatan uji $80 \%$, prevalensi kejadian DE pada pasien MetS sebesar 50\% dan OR=3 (Risiko DE pada MetS) (6) serta dilakukan matching dengan perbandingan besar sampel kasus dan kontrol adalah 1:1 sehingga sampel minimal untuk kasus dan kontrol masing-masing sebanyak 38 orang. Pengambilan sampel menggunakan cara nonprobability sampling dengan teknik consecutive sampling yaitu cara pengambilan sampel yang memenuhi kriteria untuk dimasukkan dalam penelitian sampai memenuhi jumlah minimal yang ditentukan. Subjek dikategorikan mengalami MetS jika terdiagnosis DM tipe 2 berdasarkan

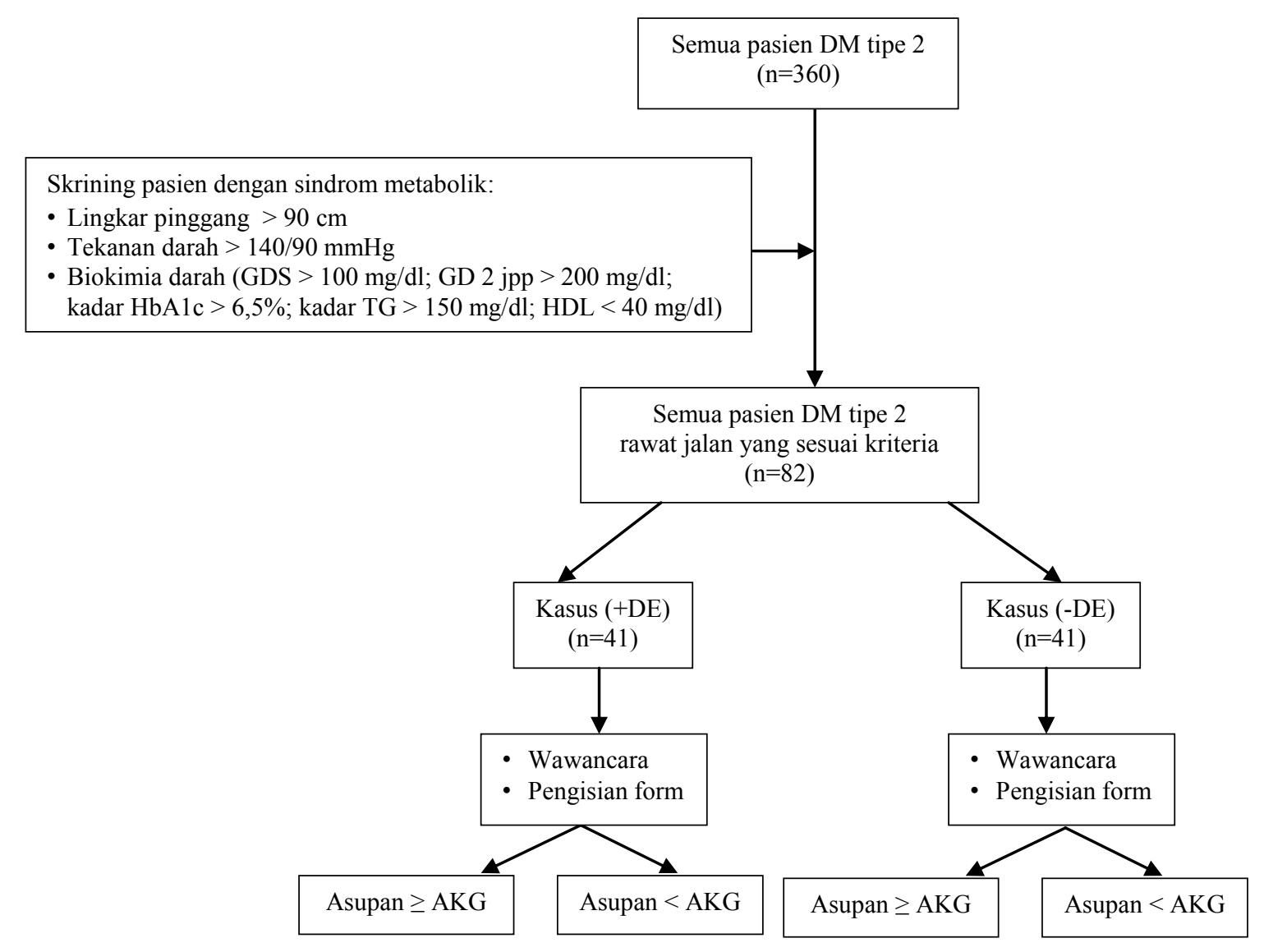

Gambar 1. Skema pengambilan sampel 
pemeriksaan glukosa darah puasa (GDP $>100 \mathrm{mg} / \mathrm{dl}$ ) dan gula darah 2 jam post prandial (GD 2 jpp $>200 \mathrm{mg}$ / dl) dengan ditambah 2 kriteria atau lebih sesuai kriteria WHO yaitu hipertensi (TD $>140 / 90 \mathrm{mmHg}$ ), trigliserida tinggi ( $\mathrm{TG}>150 \mathrm{mg} / \mathrm{dl}$ ), high density lipoprotein rendah ( $\mathrm{HDL}<40 \mathrm{mg} / \mathrm{dl})$, dan obesitas abdomen $(\mathrm{LP}>90 \mathrm{~cm})$

\section{(21) (Gambar 1).}

Variabel yang diamati meliputi variabel bebas yaitu asupan $\mathrm{Zn}$ dan $\mathrm{Mg}$; variabel terikat adalah kejadian DE; dan variabel luar antara lain merokok, konsumsi alkohol, dan aktivitas fisik. Disfungsi ereksi adalah keadaan penderita yang ditandai dengan ketidakmampuan untuk mencapai atau mempertahankan ereksi yang cukup untuk melakukan hubungan seksual yang memuaskan, yang menetap normal selama 3 bulan terakhir, yang diperoleh dari wawancara dengan mengunakan kuesioner International Index of Erectile Function-5 (IIEF-5) dengan kategori DE jika skor IIEF-5 kurang dari atau sama dengan 20 poin (22).

Data asupan $\mathrm{Zn}$ dan $\mathrm{Mg}$ diperoleh dari konsumsi makanan subjek dalam kurun waktu 3 bulan terakhir menggunakan semi-quantitative food frequency questionnaire (SQFFQ) dengan kategori Zn cukup $(\geq 13,4 \mathrm{mg}$ ) dan kurang $(<13,4 \mathrm{mg})$, demikian juga dengan kategori Mg cukup $(\geq$ $300 \mathrm{mg}$ ) dan kurang $(<300 \mathrm{mg}$ ) (angka kecukupan gizi/ AKG 2004). Aktivitas fisik dikategorikan cukup jika subjek melakukan aktivitas fisik yang sedang selama lebih dari atau sama dengan $30 \mathrm{menit} / \mathrm{hari}$ sebanyak lebih dari atau sama dengan 3 hari/minggu (23).
Data penelitian yaitu karakteristik responden, hasil pemeriksaan laboratorium, dan data penunjang diambil dari rekam medis menggunakan panduan kuesioner. Data DE diperoleh melalui wawancara langsung dengan panduan kuesioner IIEF-5 dan dilengkapi data kekerasan ereksi yang diperoleh menggunakan alat bantu patient-reported outcome (PRO) untuk menentukan Erection Hardness Score (EHS) yang dilakukan oleh enumerator terlatih yaitu dokter umum. Data asupan $\mathrm{Zn}$ dan $\mathrm{Mg}$ diperoleh dengan metode wawancara menggunakan SQFFQ dibantufood models yang dilakukan oleh enumerator yang telah dilatih yaitu sarjana kesehatan masyarakat (SKM) peminatan gizi dan DIV gizi. Pengukuran lingkar perut menggunakan pita ukur lingkar perut dengan ketelitian $0,1 \mathrm{~cm}$.

Analisis dalam penelitian ini adalah analisis Chi-Square untuk melihat hubungan dan kekuatan hubungan antara variabel terikat dan variabel bebas. Apabila hasil uji bivariat mempunyai nilai $p$ kurang dari 0,25 maka variabel tersebut dapat masuk dalam analisis multivariat (24) regresi logistik ganda (beberapa variabel independen dan satu variabel dependen). Penelitian ini sudah memperoleh ethical clearance dari Komisi Etik Penelitian Kedokteran dan Kesehatan Fakultas Kedokteran Universitas Gadjah Mada.

\section{HASIL}

Selama periode pengambilan data, diperoleh sebanyak 82 subjek yang memenuhi kriteria inklusi

Tabel 1. Distribusi karakteristik subjek penelitian

\begin{tabular}{|c|c|c|c|c|c|}
\hline \multirow{2}{*}{ Karakteristik } & \multicolumn{2}{|c|}{ Kasus } & \multicolumn{2}{|c|}{ Kontrol } & \multirow[b]{2}{*}{$\mathbf{p}$} \\
\hline & $\mathrm{n}$ & $\%$ & $\mathrm{n}$ & $\%$ & \\
\hline Umur $($ mean \pm SD) & \multicolumn{2}{|c|}{$51,2 \pm 4,67$} & \multicolumn{2}{|c|}{$49,3 \pm 4,48$} & 0,114 \\
\hline \multicolumn{6}{|l|}{ Kategori skor IIEF-5 } \\
\hline Berat $(5-10)$ & 8 & 19,5 & 0 & 0 & \\
\hline Sedang (11-16) & 29 & 70,7 & 0 & 0 & \\
\hline Ringan (17-20) & 4 & 9,8 & 0 & 0 & \\
\hline Tidak DE (21-25) & 0 & 0 & 41 & 100 & \\
\hline \multicolumn{6}{|l|}{ Erection hardness score } \\
\hline $0=$ Penis tidak membesar & 0 & 0 & 0 & 0 & \\
\hline $1=$ Penis membesar tapi tidak keras & 6 & 14,6 & 0 & 0 & \\
\hline $2=$ Penis dapat keras tetapi tidak cukup untuk penetrasi & 33 & 80,5 & 0 & 0 & \\
\hline $3=$ Penis cukup keras untuk penetrasi tetapi tidak maksimal kekerasannya & 2 & 4,9 & 27 & 65,9 & \\
\hline 4=Penis maksimal kekerasannya dan kaku & 0 & 0 & 14 & 34,1 & \\
\hline
\end{tabular}

Keterangan: IIEF-5 = international index of erectile function-5; $\mathrm{DE}=$ disfungsi ereksi; $\mathrm{SD}=$ standar deviasi 
dengan matching umur yaitu terdiri dari 41 subjek kelompok kasus dan 41 subjek kelompok kontrol dengan karakteristik yang terlihat pada Tabel 1. Berdasarkan hasil analisis menunjukkan bahwa tidak ada perbedaan karakteristik subjek berdasarkan umur antara kelompok kasus dan kontrol $(\mathrm{p}=0,114)$. Apabila hasil penelitian dengan IIEF-5 dikelompokkan menjadi empat kategori DE (3), diperoleh bahwa subjek terbanyak pada kelompok kasus berada pada kategori sedang $(70,7 \%)$ sedangkan kelompok kontrol semua berada pada kategori tidak mengalami DE (100\%). Hasil penentuan DE dengan IIEF-5 didukung data kekerasan ereksi berdasarkan EHS menunjukkan hasil bahwa skor terbanyak pada kelompok kasus yaitu skor $2(80,5 \%)$ sedangkan pada kelompok kontrol yaitu skor $3(65,9 \%)$.

Subjek pada kelompok kasus lebih banyak yang tergolong asupan Zn kurang $(95,1 \%)$, demikian juga pada kelompok kontrol (73,2\%). Subjek dengan asupan Zn kurang memiliki risiko 7,15 kali lebih besar untuk menjadi DE dibandingkan subjek dengan asupan $\mathrm{Zn}$ yang

Tabel 2. Hubungan asupan $\mathrm{Zn}$ dan Mg dengan disfungsi ereksi

\begin{tabular}{lcccccccc}
\hline \multicolumn{1}{c}{$\begin{array}{c}\text { Asupan zat gizi } \\
\text { (per hari) }\end{array}$} & \multicolumn{2}{c}{ Kasus } & \multicolumn{2}{c}{ Kontrol } & \multirow{2}{*}{ OR } & \multirow{2}{*}{$\mathbf{9 5 \% C l}$} & \multirow{2}{*}{$\mathbf{p}$} \\
\cline { 2 - 5 } & $\mathbf{n}$ & $\mathbf{\%}$ & $\mathbf{n}$ & $\mathbf{\%}$ & & & & \\
\hline Asupan Zn & 39 & 95,1 & 30 & 73,2 & 7,15 & $(1,47-34,71)$ & 0,007 \\
$\quad$ Kurang & 2 & 4,9 & 11 & 26,8 & & & \\
$\quad$ Cukup & & & & & & & \\
Asupan Mg & 13 & 31,7 & 5 & 12,2 & 3,34 & $(1,07-10,49)$ & 0,033 \\
$\quad$ Kurang & 28 & 68,3 & 36 & 87,8 & & & \\
$\quad$ Cukup & & & & & & & & \\
\hline
\end{tabular}

Tabel 3. Hubungan faktor risiko Mets dan variabel luar dengan disfungsi ereksi

\begin{tabular}{|c|c|c|c|c|c|c|c|}
\hline \multirow{2}{*}{ Variabel } & \multicolumn{2}{|c|}{ Kasus } & \multicolumn{2}{|c|}{ Kontrol } & \multirow{2}{*}{$95 \% \mathrm{Cl}$} & \multirow{2}{*}{ OR } & \multirow{2}{*}{$\mathbf{p}$} \\
\hline & $\mathbf{n}$ & $\%$ & $\mathrm{n}$ & $\%$ & & & \\
\hline \multicolumn{8}{|l|}{ Merokok } \\
\hline Ya & 37 & 90,2 & 24 & 58,5 & $1,97-21,85$ & 6,55 & 0,001 \\
\hline Tidak & 4 & 9,8 & 17 & 41,5 & & & \\
\hline \multicolumn{8}{|l|}{ Konsumsi alkohol } \\
\hline $\mathrm{Ya}$ & 5 & 12,2 & 3 & 7,3 & $0,39-7,90$ & 1,76 & 0,457 \\
\hline Tidak & 36 & 87,8 & 38 & 92,7 & & & \\
\hline \multicolumn{8}{|l|}{ Aktivitas fisik } \\
\hline Kurang & 23 & 56,1 & 16 & 39,0 & $0,83-4,81$ & 2,00 & 0,122 \\
\hline Cukup & 18 & 43,9 & 25 & 61,0 & & & \\
\hline \multicolumn{8}{|l|}{ Kadar HbA1c (\%) } \\
\hline Tidak terkontrol $(\geq 6,5)$ & 34 & 82,9 & 12 & 29,3 & $4,09-33,70$ & 11,70 & 0,000 \\
\hline Terkontrol $(<6,5)$ & 7 & 17,1 & 29 & 70,7 & & & \\
\hline \multicolumn{8}{|l|}{ Kadar HDL (mg/dl) } \\
\hline Rendah $(<40)$ & 28 & 68,3 & 14 & 34,1 & $1,65-10,40$ & 4,15 & 0,002 \\
\hline Normal $(\geq 40)$ & 13 & 31,7 & 27 & 65,9 & & & \\
\hline \multicolumn{8}{|l|}{ Kadar trigliserida (mg/dl) } \\
\hline Tinggi $(>150)$ & 38 & 92,7 & 33 & 80,5 & $0,33-0,80$ & 3,07 & 0,105 \\
\hline Normal $(\leq 150)$ & 3 & 7,3 & 8 & 19,5 & & & \\
\hline \multicolumn{8}{|l|}{ Hipertensi (mmHg) } \\
\hline Hipertensi (TD>140/90) & 22 & 53,7 & 16 & 39,0 & $0,75-4,35$ & 1,81 & 0,184 \\
\hline Tidak hipertensi $(\mathrm{TD} \leq 140 / 90)$ & 19 & 46,3 & 25 & 61,0 & & & \\
\hline \multicolumn{8}{|l|}{ Obesitas abdominal } \\
\hline Obesitas $(\mathrm{LP}>90 \mathrm{~cm})$ & 39 & 95,1 & 29 & 70,7 & $1,68-38,90$ & 8,07 & 0,003 \\
\hline Tidak obesitas $(\mathrm{LP} \leq 90 \mathrm{~cm})$ & 2 & 4,9 & 12 & 29,3 & & & \\
\hline
\end{tabular}

Keterangan: $\mathrm{HbA1c}=$ hemoglobin glikosilat; $\mathrm{HDL}=$ high density lipoprotein $; \mathrm{TD}=$ tekanan darah; $\mathrm{LP}=$ lingkar pinggang 
Saraheni, dkk: Asupan zink dan magnesium makanan dengan disfungsi ereksi pada penderita sindrom metabolik

Tabel 4. Analisis multivariat hubungan asupan $\mathrm{Zn}$, Mg, faktor risiko Mets, dan variable luar dengan disfungsi ereksi

\begin{tabular}{|c|c|c|c|c|c|c|}
\hline & \multirow{2}{*}{ Variabel } & \multirow{2}{*}{ B } & \multirow{2}{*}{$\mathbf{p}$} & \multirow{2}{*}{ OR } & \multicolumn{2}{|c|}{$95 \%$ CI } \\
\hline & & & & & Lower & Upper \\
\hline \multirow[t]{9}{*}{ Step 1(a) } & Asupan $\mathrm{Zn}$ & 2.398 & .025 & 10.998 & 1.356 & 89.200 \\
\hline & Asupan $\mathrm{Mg}$ & .892 & .303 & 2.441 & .446 & 13.351 \\
\hline & Merokok & .893 & .273 & 2.444 & .495 & 12.066 \\
\hline & Aktivitas fisik & .596 & .378 & 1.815 & .482 & 6.831 \\
\hline & Kadar $\mathrm{HbAlc}$ & 2.172 & .005 & 8.779 & 1.915 & 40.236 \\
\hline & HDL & .362 & .633 & 1.436 & .326 & 6.323 \\
\hline & Hipertensi & 1.589 & .036 & 4.901 & 1.105 & 21.731 \\
\hline & Obesitas abdominal & 2.004 & .053 & 7.419 & .977 & 56.339 \\
\hline & Kadar trigliserida & 2.073 & .035 & 7.952 & 1.154 & 54.789 \\
\hline \multirow[t]{8}{*}{ Step 2(a) } & Asupan Zn & 2.443 & .021 & 11.504 & 1.448 & 91.377 \\
\hline & Asupan $\mathrm{Mg}$ & .972 & .252 & 2.644 & .500 & 13.973 \\
\hline & Merokok & 1.004 & .195 & 2.729 & .599 & 12.437 \\
\hline & Aktivitas fisik & .667 & .312 & 1.949 & .535 & 7.103 \\
\hline & Kadar HbAlc & 2.313 & .002 & 10.103 & 2.416 & 42.257 \\
\hline & Hipertensi & 1.556 & .039 & 4.739 & 1.079 & 20.814 \\
\hline & Obesitas abdominal & 1.914 & .060 & 6.781 & .923 & 49.825 \\
\hline & Kadar trigliserida & 1.990 & .036 & 7.313 & 1.136 & 47.093 \\
\hline \multirow[t]{7}{*}{ Step 3(a) } & Asupan Zn & 2.299 & .026 & 9.968 & 1.317 & 75.420 \\
\hline & Asupan $\mathrm{Mg}$ & .892 & .284 & 2.440 & .477 & 12.491 \\
\hline & Merokok & 1.100 & .143 & 3.004 & .690 & 13.077 \\
\hline & Kadar $\mathrm{HbAlc}$ & 2.354 & .001 & 10.525 & 2.570 & 43.109 \\
\hline & Hipertensi & 1.544 & .040 & 4.684 & 1.073 & 20.453 \\
\hline & Obesitas abdominal & 1.863 & .060 & 6.445 & .926 & 44.861 \\
\hline & Kadar trigliserida & 2.011 & .032 & 7.468 & 1.189 & 46.910 \\
\hline \multirow[t]{6}{*}{ Step 4(a) } & Asupan Zn & 2.538 & .013 & 12.653 & 1.702 & 94.036 \\
\hline & Merokok & 1.063 & .150 & 2.894 & .681 & 12.293 \\
\hline & Kadar $\mathrm{HbAlc}$ & 2.311 & .001 & 10.089 & 2.527 & 40.280 \\
\hline & Hipertensi & 1.689 & .023 & 5.414 & 1.269 & 23.097 \\
\hline & Obesitas abdominal & 1.958 & .046 & 7.083 & 1.039 & 48.292 \\
\hline & Kadar trigliserida & 2.141 & .024 & 8.504 & 1.332 & 54.311 \\
\hline \multirow[t]{5}{*}{ Step 5(a) } & Asupan Zn & 2.735 & .009 & 15.409 & 1.998 & 118.868 \\
\hline & Kadar HbAlc & 2.532 & .000 & 12.574 & 3.258 & 48.526 \\
\hline & Kadar trigliserida & 2.349 & .017 & 10.475 & 1.522 & 72.098 \\
\hline & Obesitas abdominal & 1.937 & .045 & 6.936 & 1.043 & 46.114 \\
\hline & Hipertensi & 1.761 & .015 & 5.816 & 1.398 & 24.194 \\
\hline
\end{tabular}

cukup ( $\mathrm{p}=0,007)$. Kelompok kasus dan kontrol sama-sama menunjukkan proporsi subjek terbanyak dengan asupan Mg cukup (68,3\% dan 87,8\%). Hasil analisis menunjukan hubungan yang bermakna antara asupan $\mathrm{Mg}$ dan DE dengan nilai OR adalah 3,34 ( $\mathrm{p}=0,033)$ Tabel 2.

Hasil penelitian pada Tabel 3 menunjukkan ada hubungan yang bermakna secara statistik antara merokok dengan DE dan subjek yang merokok berisiko 6,55 kali lebih besar untuk terkena DE dibandingkan subjek yang tidak merokok $(p=0,001)$. Sebagian besar subjek pada kelompok kasus dan kontrol menyatakan merokok dengan rerata jumlah rokok yang dihisap setiap hari hampir sama antara kasus dan kontrol yaitu 5 batang. Hasil laboratorium kadar HbA1c dan kadar HDL menunjukkan hubungan yang bermakna secara statistik dengan kejadian DE ( $p=0,000$ dan $p=0,002)$. Selain itu, hasil analisis juga menunjukkan hubungan yang bermakna antara obesitas abdominal dengan DE $(p=0,003)$. Konsumsi minuman beralkohol, aktivitas fisik, kadar trigliserida, dan hipertensi menunjukkan hubungan 
yang tidak bermakna dengan DE baik pada kelompok kasus maupun kontrol.

Setiap variabel secara interaktif yang paling berisiko menyebabkan DE pada pasien MetS dapat dilihat pada Tabel 4. Hasil akhir analisis multivariat menunjukkan bahwa variabel yang paling berisiko menyebabkan DE pada pasien MetS terlihat dari nilai OR adalah asupan $\mathrm{Zn}$ yaitu 15,4 (95\% $\mathrm{Cl}=2,62-34,4$; $\mathrm{p}=0,009)$, kemudian diikuti kadar HbA1c dengan nilai $\mathrm{OR}=12,6(95 \% \mathrm{Cl}=1,35-52,4 ; \mathrm{p}=0,000)$. Artinya, subjek dengan asupan $\mathrm{Zn}$ kurang dan kadar HbA1c yang tidak terkontrol memiliki risiko 15,4 dan 12,6 kali lebih besar untuk mengalami DE dibandingkan dengan subjek yang asupan Zn cukup dan kadar HbA1c terkontrol. Tabel 4 juga menunjukkan bahwa kadar trigliserida mempunyai nilai $\mathrm{OR}=10,5(95 \% \mathrm{CI}=0,8-15,6 ; \mathrm{p}=0,017)$ dan obesitas abdominal dengan $\mathrm{OR}=6,94(95 \% \mathrm{CI}=1,04-46,11$; $\mathrm{p}=0,045)$, berarti subjek dengan kadar trigliserida tinggi dan obesitas abdominal mempunyai risiko lebih besar terkena DE dibandingkan subjek dengan kadar trigliserida normal dan tidak obesitas. Hasil uji statistik multivariat menunjukkan nilai OR terendah pada variabel hipertensi dengan nilai $\mathrm{OR}=5,82(95 \% \mathrm{CI}=0,9-11,1 ; \mathrm{p}=0,015)$. Hasil analisis multivariat pada penelitian ini diperoleh asupan zink, kadar HbA1c, kadar trigliserida, obesitas abdominal, dan hipertensi secara klinis dan statistik menunjukkan hubungan yang positif terhadap kejadian DE.

\section{BAHASAN}

\section{Karakteristik subjek penelitian}

Subjek pada penelitian ini dilakukan matching umur (30-60 tahun), dengan demikian umur pada kelompok kasus dan kontrol adalah sama sehingga faktor risiko dari umur dapat dikendalikan dan diperoleh hubungan yang lebih kuat antara variabel yang sedang diteliti dengan kejadian DE. Uji statistik menunjukkan bahwa tidak ada perbedaan yang bermakna pada umur antara kelompok kasus dan kontrol. Rerata umur pada kelompok kasus yaitu 51,2 tahun $(\mathrm{SD} \pm 4,67)$ dan pada kelompok kontrol yaitu 49,3 tahun $(\mathrm{SD} \pm 4,48)$. Hasil penelitian sebelumnya yang dilakukan di empat negara (Jepang, Malaysia, Italia, dan Brazil) (25) menyebutkan bahwa risiko menderita DE meningkat $10 \%$ setiap tahun pada populasi pria umur 40-70 tahun dengan OR disfungsi ereksi sedang dan berat setiap orang setiap tahun adalah $1,10(95 \% \mathrm{Cl}=1,08-1,11)$.

Penelitian sebelumnya juga menyebutkan bahwa aterosklerosis berhubungan dengan kasus DE sebanyak $40 \%$ pada laki-laki berusia di atas 50 tahun. Vitamin E dan Zn khususnya berperan penting dalam memelihara sistem imun. Defisiensi Zn jangka panjang menurunkan produksi sitokin dan merusak pengaturan aktivasi sel helper $\mathrm{T}$, menyebabkan perubahan kompartemen sel $\mathrm{T}$ yang terjadi sebagai hasil involusi timus untuk menghasilkan interleukin 10 (IL-10), perubahan subtansial pada fungsional dan fenotif profil sel $\mathrm{T}$ dilaporkan sesuai dengan peningkatan usia, dan pada usia yang bertambah tua cenderung menghasilkan autoantibodi yang mengarah pada penyakit autoimun. Autoantibodi adalah faktor penyebab artritis reumatoid dan aterosklerosis (12). Lebih lanjut, aterosklerosis merupakan predisposisi menyebabkan DE vaskulogenik (16).

Hasil penelitian ini sesuai dengan Massachusetts Male Aging Study (MMAS) yang melakukan penelitian pada 1290 orang laki-laki berumur 40-70 tahun, berdasarkan IIEF-5 diperoleh $42 \%$ menderita DE dengan kategori berat sebesar $17,1 \%$; sedang $25,2 \%$; dan sisanya $9,6 \%$ berada pada kategori ringan (26). Sementara itu, hasil yang diperoleh untuk tingkat kekerasan ereksi dengan menggunakan EHS ditemukan sebanyak 50\% pasangan dengan kepuasan maksimal dalam kehidupan seksual. Penelitian tersebut bermakna secara statistik ( $p=0,01)$, artinya ada hubungan uji EHS dengan kepuasan yang maksimal dalam kehidupan seksual pasangan (27).

\section{Hubungan asupan Zn dan Mg dengan disfungsi ereksi}

Hasil penelitian ini menunjukkan bahwa ada hubungan antara asupan Zn dengan kejadian DE. Zink diperlukan tubuh dalam jumlah yang sedikit, tetapi $\mathrm{Zn}$ memegang peranan esensial pada semua sel dan apabila terjadi defisiensi $\mathrm{Zn}$ akan menyebabkan perubahan yang luas karena $\mathrm{Zn}$ dapat menstimulasi aktivitas 100 macam enzim dan terlibat sebagai kofaktor pada 200 jenis enzim lainnya. Zink dinyatakan sebagai mineral yang berperan untuk meningkatkan reaksi biokimia di 
dalam tubuh yang ada hubungannya dengan metabolisme karbohidrat dan organ-organ reproduksi pria, perubahan testosteron menjadi dehidrotestosteron yang aktif (11). Zink sangat berperan dalam reproduksi berkaitan dengan kekurangan dehidrotestosteron pada tingkatan berat dan sedang, yang berhubungan dengan hipogonadisme dan kesuburan pada laki-laki. Hasil studi cross-sectional menunjukan bahwa kadar serum testosteron berhubungan secara bermakna dengan kadar Zn yaitu limposit Zn dengan kadar testosteron $(\mathrm{p}=0,006)$ dan granulosit $\mathrm{Zn}$ dengan kadar testosteron $(p=0,03)$. Selain itu, kekurangan asupan $\mathrm{Zn}$ berhubungan dengan penurunan kadar serum testosteron setelah 20 minggu ( $\mathrm{p}=0,005)$ dengan standar recommended daily allowance (RDA) di Amerika Serikat sebesar 137,7 mg (28). Dijelaskan lebih lanjut bahwa kadar testosteron merupakan faktor yang biasa dihubungkan dengan kejadian DE seperti arterosklerosis (29).

Peran Zn sebagai antioksidan (SOD, katalase, peroksidase) yaitu $\mathrm{Zn}$ metallothionein komplek dalam inti sel mencegah radikal bebas. Pada semua sel, $\mathrm{Zn}$ berperan sebagai komponen SOD untuk transfer radikal superoksida yang relatif tinggi dan sebagai proteksi struktur seluler terhadap kerusakan oksidatif (30). Zink berperan penting dalam mencegah radikal bebas yang menyebabkan kerusakan pada arteri yang menjurus pada penyempitan pembuluh darah yang berbahaya (aterosklerosis), yang menyebabkan bagian yang dipasok darah akan mengalami kelainan atau gangguan fungsi dan apabila pasokan darah ke organ penis terhambat maka akan menyebabkan DE (31). Selain itu, berdasarkan hasil wawancara dengan SQFFQ diketahui bahwa sebagian besar subjek tidak selalu mengonsumsi daging, makanan laut, gandum, dan produk-produk susu. Padahal sumber terbaik $\mathrm{Zn}$ adalah daging, sea food, gandum dan susu, bahkan susu menyumbang $80 \%$ untuk kebutuhan Zn. Di dalam tubuh, sistem penyerapan $\mathrm{Zn}$ yang berasal dari sumber hewani berlangsung lebih baik daripada yang berasal dari bahan nabati (32).

Hasil penelitian ini menggambarkan bahwa dari 82 subjek baik pada kelompok kasus maupun kontrol, ditemukan 54 subjek $(65,9 \%)$ yang tercatat mengonsumsi minuman teh 1-3 gelas per hari dan menyukai sayuran sebagai variasi menu pada diit yang mereka jalani. Hal ini dikaitkan dengan penyebab utama penghambatan penyerapan $\mathrm{Zn}$ yaitu tingginya kadar asam fitat dalam gandum-ganduman, serealia, kacang-kacangan, dan sebagainya. Asam fitat dan serat tidak larut air dapat bertindak sebagai antinutrisi yang mekanisme kerjanya adalah menghambat penyerapan Zn (33).

Lebih lanjut, hasil penelitian ini menunjukkan hubungan yang bermakna secara statistik antara asupan $\mathrm{Mg}$ dan DE. Subjek dengan asupan Mg kurang memiliki risiko 3,34 kali lebih besar untuk mengalami DE dibandingkan subjek dengan asupan Mg cukup. Sesuai dengan penelitian yang dilakukan di Amerika Serikat (34) pada subjek dengan risiko aterosklerosis $(n=323)$, diperoleh hasil bahwa ada hubungan antara asupan $\mathrm{Mg}$ yang rendah dengan risiko kejadian stroke iskemik dengan adanya risiko aterosklerosis $(p=0,005)$. Kekurangan Mg berhubungan dengan peningkatan kadar sitokin sebagai pemicu oksidatif di endotelia karena dinding dalam (endotel) pada otot-otot polos (sinusoid) di dalam penis yang sangat berperan dalam bereaksi untuk menghasilkan ereksi menjadi ikut terganggu. Disfungsi endotel memicu aterosklerosis yang merupakan faktor penyebab pada kasus DE (35).

\section{Hubungan faktor risiko Mets dan variabel luar dengan disfungsi ereksi}

Hubungan antara faktor luar yaitu merokok dengan DE menunjukkan bahwa subjek yang merokok berisiko 6,55 kali lebih besar untuk terkena DE dibandingkan subjek yang tidak merokok. Studi MMAS yang dilakukan selama 9 tahun menemukan bahwa risiko berkembangnya DE pada perokok mendekati 2 kali lipat $(\mathrm{OR}=1,97)$ lebih besar dibandingkan bukan perokok. Namun, dalam studi ini tidak didapatkan hubungan antara DE dengan jumlah rokok yang dihisap per hari. Rokok merupakan faktor risiko berkembangnya perubahan vaskular aterosklerosis dan memegang peran dalam perkembangan vaskulogenik DE. Penelitian pada 440 pasien dengan DE menjelaskan bahwa perokok pasif juga secara bermakna sebagai prediktor kejadian DE. Penggunaan tembakau berhubungan dengan meningkatnya perubahan aliran arteri, kemampuan hiperkoagulan, meningkatnya agregasi plaletet, meningkatkan pelepasan asam lemak bebas dan katekolamin, perubahan dalam nitrit oksida 
(NO) synthetic pathways, serta efek toksik pada vaskular endotelium. Perokok aktif dan pasif berhubungan dengan disfungsi endotel $(10,36)$.

Berbeda dengan dua faktor luar lain yaitu konsumsi alkohol dan aktivitas fisik yang tidak menunjukkan hubungan bermakna dengan kejadian DE. Sebagian besar subjek tidak mengonsumsi minuman beralkohol sedangkan aktivitas fisik kurang ditemukan lebih banyak pada kelompok kasus $(56,1 \%)$ dan sebaliknya aktivitas fisik cukup jumlahnya lebih banyak pada kelompok kontrol (61\%). Rerata jumlah waktu untuk beraktivitas fisik yang dilakukan oleh subjek setiap harinya adalah 59 menit, tetapi dilakukan rata-rata hanya 2 hari per minggu.

Sementara itu, untuk faktor risiko MetS penyebab DE yang menunjukkan hubungan bermakna adalah kadar HbA1c, HDL, dan obesitas abdominal sedangkan kadar trigliserida dan hipertensi tidak menunjukkan hubungan yang bermakna secara statistik. HbA1c adalah komponen $\mathrm{Hb}$ yang terbentuk dari reaksi non-enzimatik. HbA1c akan meningkat secara bermakna jika glukosa darah meningkat. Oleh karena itu, HbA1c bisa digunakan untuk melihat kualitas kontrol glukosa darah pada penderita DM sejak 3 bulan lalu (umur eritrosit). Nilai yang dianjurkan Perkumpulan Endokrinologi Indonesia (PERKENI) tahun 2006 untuk HbA1c (terkontrol) adalah kurang dari 6,5\%. Jadi, HbA1c penting untuk melihat apakah penatalaksanaan sudah adekuat atau belum (37). Menurut besarnya nilai OR, kadar HbA1c yang tidak terkontrol berisiko 11,7 kali lebih besar untuk mengalami DE dibandingkan subjek dengan kadar HbA1c yang terkontrol $(\mathrm{p}=0,000)$.

Kadar gula darah berhubungan dengan kejadian DE yaitu kadar gula darah yang secara dinamis berubah terkadang menyebabkan terjadi DE secara tiba-tiba (mendadak). Hal ini terjadi bukan karena neuropati, tetapi karena dinding dalam (endotel) pada otot-otot polos (sinusoid) di dalam penis yang sangat berperan bereaksi untuk menghasilkan ereksi menjadi ikut terganggu (38). Tingginya kadar gula darah yang tidak terkontrol dapat menyebabkan terjadinya kerusakan (neuropati) pada ujung-ujung saraf parasimpati yang mengakibatkan rongga-rongga ruang pembuluh darah (corpus cavernosum) tidak mendapat tambahan darah secara maksimal yang mengakibatkan penis tidak bisa mengembang dan ereksi (39).
Lebih lanjut, kadar HDL yang rendah dalam darah berisiko 4,15 kali lebih besar untuk terkena DE. Penelitian lain menyebutkan ada hubungan yang bermakna antara kadar serum $\mathrm{Zn}(\mathrm{p}<0,01)$ dan $\mathrm{Cu}$ $(p<0,05)$ dengan lipoperoxidemia dan HDL kolesterol pada kasus uremia kronik pasien hemodialisis. Dengan kata lain, rendahnya kadar serum $\mathrm{Zn}$ dan $\mathrm{Cu}$ berkontribusi menurunkan kadar HDL kolesterol yang akan berisiko tinggi terkena aterosklerosis (29). Penyakit vaskuler merupakan penyebab yang paling sering menimbulkan DE (8). Hubungan antara obesitas dan DE menunjukkan hasil bahwa subjek yang obesitas berisiko 8,07 kali lebih besar untuk terkena DE dibandingkan subjek yang tidak obesitas. Hubungan antara obesitas dan DE sulit diketahui dengan pasti karena eratnya hubungan antara obesitas dan penyakit-penyakit degeneratif. "The MMAS 9 year follow up study" menyatakan bahwa obesitas abdominal merupakan prediktor independen untuk DE dengan adjusted $\mathrm{OR}=1,96$. Obesitas abdominal berhubungan dengan "level of circulating androgens" yang memberikan kontribusi independen dalam berkembangnya DE (10). Obesitas berimplikasi terhadap DE (40). Suatu studi melaporkan sebanyak 79\% laki-laki DE mengalami obesitas abdominal (37).

Di samping itu, kadar trigliserida jika dihubungkan dengan DE diperoleh hasil bahwa pada kelompok kasus maupun kontrol, jumlah terbanyak yaitu subjek dengan kadar trigliserida tinggi (92,7\% dan 80,5\%). Kadar trigliserida dihubungkan dengan kejadian DE menunjukkan nilai $\mathrm{OR}=0,33(95 \% \mathrm{Cl}=0,8-1,33 ; \mathrm{p}=0,105)$. Hipertrigliserida juga terjadi karena sekresi berlebihan dari partikel trigliserida yang kaya akan very low density lipoprotein (VLDL). Rerata peningkatan pengambilan asam lemak bebas oleh hepar menstimulus sekresi dari $\beta$-100, yang mengakibatkan meningkatnya jumlah apo- $\beta$ yang berisi partikel dan kemungkinan hipertrigliseridemia (39). Penelitian ini didukung dengan hasil penelitian sebelumnya yang menyatakan bahwa hiperlipidemia berhubungan dengan berkembangnya penyakit pembuluh darah aterosklerotik hingga kontribusinya dalam vaskulogenik DE. Dalam studi tersebut dilaporkan bahwa risiko DE 1,83 kali lebih besar pada laki-laki dengan kadar total kolesterol di atas $240 \mathrm{mg} / \mathrm{dl}$ dibandingkan laki-laki dengan kadar total kolesterol $180 \mathrm{mg} / \mathrm{dl}$ (10). 


\section{Analisis multivariat}

Pada langkah terakhir dari analisis multivariat, variabel yang menunjukkan paling berisiko menyebabkan DE pada pasien MetS berdasarkan nilai OR adalah asupan Zn dengan nilai $\mathrm{OR}=15,4$ dibandingkan hasil bivariat yaitu nilai $\mathrm{OR}=7,15$. Artinya, subjek dengan asupan Zn kurang memiliki risiko yang meningkat 8,25 kali lebih besar untuk mengalami DE dibandingkan dengan subjek yang dengan asupan $\mathrm{Zn}$ cukup. Apabila asupan $\mathrm{Zn}$ disertai faktor-faktor risiko yang berkaitan sebagai penyebab $\mathrm{DE}$, hasil analisis multivariat menunjukkan kadar $\mathrm{HbA}$ 1 c yang tidak terkontrol dengan nilai $\mathrm{OR}=12,57$; kadar trigliserida yang tinggi dengan nilai $\mathrm{OR}=10,48$; obesitas abdominal dengan nilai $\mathrm{OR}=6,94$; dan hipertensi dengan nilai $\mathrm{OR}=5,82$. Hasil ini menunjukkan bahwa faktor-faktor tersebut harus dipertimbangkan karena akan memperburuk atau mengantisipasi terjadinya DE di samping asupan Zn yang kurang.

Ada hubungan antara diit dan aterosklerosis, bahwa kerusakan pada arteri yang menjurus pada penyempitan yang berbahaya adalah oleh radikal bebas (31). Enzim SOD (yang membutuhkan $\mathrm{Zn}$ dan $\mathrm{Cu}$ ) di dalam sitosol semua sel terutama eritrosit, diduga dapat memusnahkan anion superoksida yang merusak. Anionanion superoksida (radikal bebas) tersebut dapat memicu terbentuknya plak pada proses aterosklerosis sehingga aliran darah di dalam arteri menjadi tersumbat (13). Organ atau bagian yang akan dipasok darah melalui arteri yang tersumbat akan mengalami kelainan atau gangguan fungsi dan jika arteri ke organ penis terhambat maka akan menyebabkan DE. Zink sebagai metallothionein komplek dalam sel mencegah radikal bebas (32).

Variabel-variabel tersebut dapat dimodifikasi, intervensi yang dapat dilakukan adalah mencukupi kebutuhan asupan Zn dan membatasi konsumsi makanan yang meningkatkan kadar HbA1c, kadar trigliserida, tekanan darah, dan obesitas abdominal, serta mengontrol kadar HbA1c, kadar trigliserida, dan tekanan darah secara rutin. Obesitas juga merupakan variabel yang dapat diintervensi, yaitu melalui kontrol kadar gula darah yang baik dengan penekanan pada penurunan berat badan secara bertahap dengan cara modifikasi gaya hidup yaitu mengonsumsi makanan dengan menu seimbang sesuai diit DM yang sedang atau harus dijalani dan melakukan aktivitas fisik atau olahraga secara teratur.

\section{SIMPULAN DAN SARAN}

Ada hubungan yang bermakna antara asupan zat gizi $\mathrm{Zn}$ dengan DE pada pasien sindrom metabolik. Asupan Zn yang kurang berisiko 7,15 kali lebih besar mengalami DE dibandingkan yang asupan Zn-nya cukup. Uji multivariat menunjukkan bahwa nilai OR tertinggi adalah asupan $\mathrm{Zn}(\mathrm{OR}=15,4)$. Asupan $\mathrm{Zn}$ yang kurang disertai faktor-faktor risiko yang berhubungan sebagai penyebab DE, menunjukkan hasil yang harus dipertimbangkan karena akan memperburuk atau mengantisipasi terjadinya DE di samping asupan $\mathrm{Zn}$ yang kurang. Demikian juga diperoleh hubungan yang bermakna antara asupan zat gizi Mg dengan DE pada pasien sindrom metabolik dan asupan $\mathrm{Mg}$ yang kurang berisiko mengalami DE dibandingkan pasien dengan asupan Mg yang cukup.

Asupan $\mathrm{Zn}$ dan Mg terbukti terkait dengan kejadian DE sehingga hasil penelitian ini menambah wawasan ilmu gizi yang dapat dijadikan sebagai salah satu materi dalam konsultasi gizi oleh petugas kesehatan (Ahli gizi) kepada pasien dalam memodifikasi diit DM atau yang disertai penyakit degeneratif lainnya tanpa mengesampingkan tujuan dari diit DM itu sendiri. Pasien dapat disarankan untuk mengaplikasikan zat gizi tersebut yaitu salah satunya dengan memperhatikan kecukupan konsumsi zat gizi Zn dan Mg dalam menu sehari-hari. Bagi peneliti lain perlu diupayakan penelitian lanjutan terutama analisis asupan $\mathrm{Zn}$ dan $\mathrm{Mg}$ minimal yang dapat mengurangi DE serta mengetahui zat gizi lain yang berpengaruh pada kasus DE. Bagi institusi pelayanan kesehatan khususnya bagian yang terkait dengan rujukan pasien dengan keluhan DE hendaknya mampu menggunakan kuesioner IIEF-5 sebagai langkah awal dalam menilai kualitas kehidupan seksual karena problem kesehatan seksual merupakan salah satu penentu kualitas hidup manusia.

\section{RUJUKAN}

1. Hadi H. Gizi lebih sebagai tantangan baru dan implikasinya terhadap kebijakan pembangunan kesehatan nasional. Jurnal Gizi Klinik Indonesia 2004;1(2):51-8.

2. Adriansjah H, Adam J. Sindrom metabolik: pengertian, epidemiologi, dan kriteria diagnosis. Medika 2004;30:73941. 
3. Traish AM, Guay A, Feeley R, Saad F. The dark side of testosteron deficiency: I. metabolic syndrome and erectile dysfunction. J Androl 2009;30(1):10-22.

4. Kurnia Y. Sindrom X dan obesitas. Jurnal Meditek 2003;11(29):12-27.

5. Setiawan N. Kurang testosteron dan sindrom metabolik pun bikin disfungsi ereksi. [series online] 2009 [cited $2009 \mathrm{Mar}$ 8]. Available from: URL: http.//doktersehat.com

6. Demir T, Demir O, Kefi A, Comlekci A, Yesil S, Esen A. Prevalence of erectile dysfunction in patients with metabolic syndrome. Int J Urol 2006;13(4):385-8.

7. Wibowo S, Gofir A. Disfungsi ereksi: patofisiologi, etiologi, mekanisme, dan kaitannya dengan neuropati diabetika. Yogyakarta: Pustaka Cendekia press; 2007.

8. Eardley I. Pathophysiology of erectile dysfunction. Br J Diabetes Vasc Dis2007;2(4):272-6.

9. Depkes RI. Riset kesehatan dasar (Riskesdas). Laporan Provinsi Kalimantan Timur tahun 2007. Jakarta: Depkes RI; 2008.

10. Russell ST, Khandheria BK, Nehra A. Erectile dysfunction and cardiovascular disease. Mayo Clin Proc 2004;79(6);78294.

11. Linder MC. Biokimia nutrisi dan metabolisme. Jakarta: Universitas Indonesia; 1992.

12. Fatmah. Respon imunitas yang rendah pada tubuh manusia lanjut usia. Jurnal Makara Kesehatan 2006;10(1):47-53.

13. Martin GB, Markey CM, White CL. Roles of zink and other nutrien in testiculer development. In: current advance in andrology. International Proceedings Division; 1997 Mei 25-29; Monduzzi, Salzburg (Austria).

14. Almatsier S. Prinsip dasar ilmu gizi. Jakarta: Gramedia Pustaka Utama; 2002.

15. Thomas GN, Tomlinson B, Abdullah AS, Yeung VT, Chan JC, Wong KS. Association of erectile dysfunction with cardiovascular risk factors and increasing existing vascular disease in Malae Chinese type 2 diabetic patients. Diabetes Care 2005;28(8):2051-3.

16. Aytac IA, Mckinley JB, Krane RJ. The likely worldwide increase in erectile dysfunction between 1995 and 2025 and some possible policy consequences. BJU Int 1999;84(1):50-6.

17. Shiri R, Koskimaki J, Hakkinen J, Tammela TL, Huhtala H, Hakama M, Auvinen A. Effects of age, comorbidity and lifestyle factors on erectile fungction: Tampere Ageing Male Urological Study (TAMUS). Eur Urol 2003;45(5):628-33.

18. Wandell EP, Brorsson B. Assessing sexual functioning in patients with chronic disorders by using a generic health-related quality of life questionnaire. Qual Life Res 2000;9(10):1081-92.
19. Hudoyo A, Sunarya N, Mangunnegoro H. Disfungsi seksual pada laki-laki dengan paru abstruktif kronik (PPOK). J Respir Indo 1996;16(4):143-6.

20. Sastroasmoro S, Ismael S. Dasar-dasar metodologi penelitian klinis. Edisi ketiga. Jakarta: Binarupa Aksara; 2008.

21. Santoso M, Damayanti M. Sebaran prevalensi sindrom metabolik menurut kriteria idf pada penderita yang di rawat jalan dan inap di RSUD Koja periode Juni 2000-Juni 2005. Meditek 2005;13(35):16-21.

22. Lue TF. Male sexual dysfunction. In : Tanagho (eds). 16 th ed. Smith's General Urology. Connecticut: Appleton \& Lange; 2004.

23. Gibney MJ, Margetts BM, Kearney JM, Arab L. Gizi kesehatan masyarakat. Jakarta: EGC; 2009.

24. Hastono SP. Analisis multivariat: basic data analysis for health research. (Modul ke tiga). Jakarta: FKM UI; 2006.

25. Nicolosi A, Moreira ED Jr, Shirai M, Bin Mohd Tambi MI, Glasser DB. Epidemiology of erectile dysfunction in four countries: cross-national study of the prevalence and correlates of erectile dysfunction. Urology 2003;61(1):201-6.

26. Wagner G, Tejada IS. Update on male erectile dysfunction. BMJ 1998;316(7132):678-82.

27. Mulhall JP, Goldstein I, Bushmakin AG, Cappelleri JC, Hvidsten K. Validition of the erection hardness score. J Sex Med 2007;4(6):1626-34.

28. Prasad AS, Mantzoros CS, Beck FW, Hess JW, Brewer GJ. Zinc status and serum testosteron levels of healthy adults. Nutrition 1996;12(5):344-8.

29. Shabsigh R, Arver S, Channer KS, Eardley I, Fabbri A, Gooren L, Heufelder A, Jones H, Meryn S, Zitzmann M. The triad of erectile dysfunction, hypogonadism and the metabolic sindrom. Int J Pract 2008;62(5):791-8.

30. Mooradian AD, Morley JE. Micronutrient status in diabetes mellitus. Am J Clin Nutr 1987;45(5):877-95.

31. Wibowo S. Erectile dysfunction in diabetic patients: as a breakthrough. Dalam: Asdie, (ed). Naskah Lengkap Pertemuan Ilmiah Tahunan IV Endokrin.Yogyakarta; 2003.

32. Mahan LK, Stump SE. Krause's food nutrition \& diet therapy. Philadelphia, Pennsylvania: Saunders Company; 2000.

33. Budiyanto AK. Dasar-dasar ilmu gizi. edisi ke-3. Malang: Fakultas Muhammadiyah Malang; 2004.

34. Ohira T, Peacock JM, Iso H, Chambless LE, Rosamond WD, Folsom AR. Serum and dietary magnesium and risk of ischemic stroke. Am J Epidemiol 2009;169(12):1437-44.

35. Fine SR. Erectile dysfunction and comorbid diseases, androgen deficiency and diminished libido in men. J Am Osteopath Assoc 2004;104(1 Suppl 1):S9-15. 
36. Stein RA. Endhotelial dysfunction, erectile dysfunction and coronary heart disease: the pathophysiologic and clinical linkage. Rev Urol 2003;5(7):S21-27.

37. Widiyanti A, Ratulangi BT. Pemeriksaan laboratorium penderita diabetes mellitus. [serial online] 2006 [cited 2009 Mar 8]. Available from: URL: http.// www.tempo.co.id/medika/online/tmp.online.old/ pus-1.htm
38. Familia D. Seluk beluk \& fakta disfungsi seksual yang wajib anda ketahui.Yogyakarta: A Plus Books; 2010.

39. Carr MC, Brunzell JD. Abdominal obesity and dyslipidemia in the metabolic syndrome: importance of type 2 diabetes and familial combined hyperpilidemia in coronary artery disease risk. J Clin Endocinol Metab 2004;89(6):2601-7.

40. DiSilvestro RA. Zinc in relation to diabetes and oxidative disease. J Nutr 2000;130(5 Suppl):15099S-11S. 